\title{
Tetrahymanol from the phototrophic bacterium Rhodopseudomonas palustris: first report of a gammacerane triterpene from a prokaryote
}

\author{
Gisela Kleemann, ${ }^{1}$ Karl Poralla, ${ }^{1}$ Gerhard Englert, ${ }^{2}$ Helge Kuøsen, ${ }^{3}$ \\ Synnøye LiaAen-Jensen, ${ }^{3}$ Serge Neunlist ${ }^{4}$ and Michel Rohmer ${ }^{4 *}$ \\ ${ }^{1}$ Institute für Botanik, Universität Tübingen, auf der Morgenstelle 1, D 7400 Tübingen, Federal Republic of Germany \\ ${ }^{2}$ Zentrale Forschungs Einheiten, F. Hoffmann-La Roche AG, CH 4002 Basel, Switzerland \\ ${ }^{3}$ Universitetet i Trondheim, Norges Tekniske Hogskole, Institutt for Organisk Kjemi, Sem Saelands vei 8, N 7034 \\ Trondheim, Norway \\ ${ }^{4}$ Ecole Nationale Supérieure de Chimie de Mulhouse, 3 rue Alfred Werner, F 68093 Mulhouse Cedex, France
}

(Received 19 June 1990; revised 17 August 1990; accepted 29 August 1990)

\begin{abstract}
Tetrahymanol, a rare triterpene from the gammacerane series, previously detected only in a few scattered eukaryotic taxa, has been isolated for the first time from the phototrophic bacterium $R$ hodopseudomonas palustris. This extends the significance of geochemical markers from this series, which are abundant in marine sediments and palaeohypersaline environments.
\end{abstract}

\section{Introduction}

Rhodopseudomonas palustris is capable of synthesizing triterpenoids of the hopane series, a widespread family of prokaryotic membrane constituents (Rohmer et al., 1984). Thus diploptene (II), diplopterol (III) and aminobacteriohopanetriol (IV) (Fig. 1) have been reported as major triterpenoids from this bacterium (Rohmer et al., 1984; Neunlist et al., 1988; Neunlist \& Rohmer, 1988; Flesch \& Rohmer, 1988). In this communication, we report now the isolation and identification from this bacterium of tetrahymanol (I), a compound biogenetically related to the hopanoids. This rare triterpene has previously been found in a few scattered eukaryotic taxa, but is widespread as molecular fossil in marine sediments and palaeohypersaline environments (ten Haven et al., 1989, and references therein).

\section{Methods}

Analytical methods and growth of Rhodopseudomonas palustris DSM 123 were as previously described (Rohmer et al., 1984; Neunlist et al., 1988). NMR spectra were recorded in $\mathrm{CDCl}_{3}$ solution on a Bruker W400 spectrometer using $\mathrm{CHCl}_{3}(\delta=7.260$ p.p.m. $)$ as internal

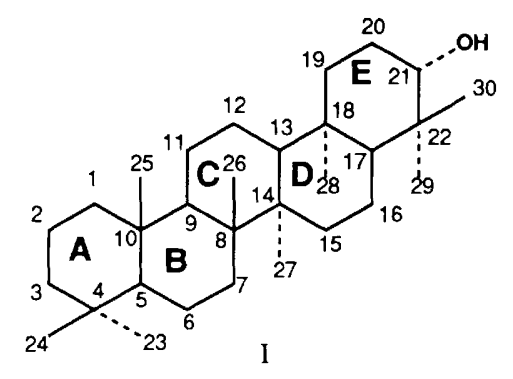
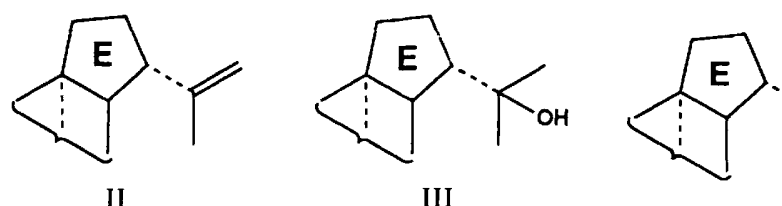<smiles>CC(C)CCC(O)[C@@H](O)C(O)CN</smiles>

Fig. 1. Triterpenoids from Rhodopseudomonas palustris: I, tetrahymanol; II, diploptene; III, diplopterol; IV, aminobacteriohopanetriol. 
standard for ${ }^{1} \mathrm{H}$-NMR and $\mathrm{CDCl}_{3}\left(\delta=77.0\right.$ p.p.m.) for ${ }^{13} \mathrm{C}-\mathrm{NMR}$. Freeze-dried cells $(15 \mathrm{~g})$ were extracted with cyclohexane under reflux $(5 \times 500 \mathrm{ml}, 1 \mathrm{~h})$. Combined extracts were evaporated to dryness and separated by TLC using methylene chloride as solvent system (two migrations). Two bands corresponding to diplopterol (II) $\left(R_{\mathrm{F}}=0 \cdot 25\right)$ and tetrahymanol (I) $\left(R_{\mathrm{F}}=0.20,0.4 \mathrm{mg}\right.$ per $\mathrm{g}$ freeze-dried cells $)$ were scraped off and studied further. Tetrahymanol was acetylated (Rohmer et al., 1984), and its acetate purified by TLC using cyclohexane/ethyl acetate $(98: 2, \mathrm{v} / \mathrm{v})$ as solvent system, in which $R_{\mathrm{F}}=0.25$. Tetrahymanone was obtained by $\mathrm{CrO}_{3} /$ pyridine oxidation in methylene chloride (Ratcliffe \& Rodehorst, 1970) and separated by TLC using methylene chloride as eluent, in which $R_{\mathrm{F}}=0.35$.

\section{Analytical Data}

\section{Tetrahymanol}

${ }^{1} \mathrm{H}-\mathrm{NMR}$ (400 MHz), $\delta$ (p.p.m.):0.757 (3H, s, 29-H), $0.787(3 \mathrm{H}, \mathrm{s}, 24-\mathrm{H}), 0.809(6 \mathrm{H}, \mathrm{s}, 25-$ and $28-\mathrm{H}), 0.841$ $(3 \mathrm{H}, \mathrm{s}, 23-\mathrm{H}), 0.951$ and $0.959(2 \times 3 \mathrm{H}, 2 \mathrm{~s}, 26-$ and $27-\mathrm{H})$, $0.967(3 \mathrm{H}, \mathrm{s}, 30-\mathrm{H}), 3.19(1 \mathrm{H}$, dd, $J 5.0 \mathrm{~Hz}, 11.5 \mathrm{~Hz}$, $21 \beta-\mathrm{H})$.

${ }^{13} \mathrm{C}-\mathrm{NMR}$ (100 MHz), $\delta$ (p.p.m.):15.4 (C-29), 16.0 (C25, C-28), 16.5 (C-26, C-27), 18.4 (C-11), 18.7 (C-2, C-6), $21 \cdot 1$ and $21 \cdot 3(\mathrm{C}-12, \mathrm{C}-16), 21 \cdot 6(\mathrm{C}-24), 27 \cdot 4(\mathrm{C}-20), 28 \cdot 0$ (C-30), 33.1 (C-7, C-17), 33.3 (C-4), 33.4 (C-23), 37.1 (C18), 37.3 (C-10), 38.7 (C-19), $38 \cdot 9$ (C-22), 40.3 (C-11), $41 \cdot 7$ and $41.9(\mathrm{C}-8, \mathrm{C}-14), 42 \cdot 1$ (C-3), $50 \cdot 2$ (C-13), 50.3 (C-9), $55 \cdot 1$ (C-17), 56.2 (C-5), 79.1 (C-21). Multiplicity of the signals was determined by DEPT (distortionless enhancement by polarization transfer) experiments. Carbon atoms are numbered as those of the hopane skeleton.

\section{Tetrahymanol acetate}

Mass spectrum (GC-MS), $m / z(\%): 470\left(\mathrm{M}^{+}, 20 \%\right), 455$ $\left(\mathrm{M}^{+}-\mathrm{CH}_{3}, 4 \%\right), 410\left(\mathrm{M}^{+}-\mathrm{AcOH}, 11 \%\right), 395\left(\mathrm{M}^{+-}\right.$ $\mathrm{AcOH}-\mathrm{CH}_{3}, 8 \%$ ), $367(2 \%), 249$ (ring $\mathrm{C}$ cleavage, $15 \%$ ), 191 (ring C cleavage, $100 \%$ ), 189 (249-AcOH, 49\%).

\section{Tetrahymanone}

Mass spectrum (GC/MS), $m / z(\%): 426\left(\mathrm{M}^{+}, 29 \%\right), 411$ $\left(\mathrm{M}^{+}-\mathrm{CH}_{3}, 13 \%\right), 370(1 \%), 232(5 \%), 205$ (ring $\mathrm{C}$ cleavage, $31 \%$ ), 191 (ring $\mathrm{C}$ cleavage, $100 \%$ ).

\section{Results and Discussion}

Tetrahymanol (I) isolated from $R$. palustris was identified by direct comparison of its analytical data $\left({ }^{1} \mathrm{H}\right.$ NMR, ${ }^{13}$ C-NMR of the alcohol, GC and GC-MS of the alcohol, its acetate and the corresponding ketone) with those of reference compounds previously isolated from the ciliate Tetrahymena pyriformis (Bouvier et al., 1980; Raederstorff \& Rohmer, 1988) or synthesized from tetrahymanol, and with those reported in the literature (Wittstruck \& Caspi, 1977; Wilkins et al., 1987). This compound is identical with paluol, a long-unidentified triterpene isolated from the same bacterium by LiaaenJensen (1962) and for which all ancient data have been now completed with ${ }^{1} \mathrm{H}(400 \mathrm{MHz})$ and ${ }^{13} \mathrm{C}(100 \mathrm{MHz})$ NMR spectroscopy.

This is the first report of the occurrence of a gammacerane-type triterpene in a prokaryote. Phylogenetically, tetrahymanol and hopanoids are closely related. They can be considered as primitive triterpenoids, since their biosynthesis does not require molecular oxygen and both series derive from a direct proton-induced, enzymecatalysed cyclization of squalene. All other triterpene series found in eukaryotes and bearing an oxygenated function at C-3 derive from the cyclization of $(3 S)$ squalene oxide, and their biosynthesis requires molecular oxygen and more complex enzymic reactions, often including transpositions (Rohmer et al., 1979; Ourisson et al., 1987, and references therein).

Until now tetrahymanol has been found only in ciliates of the genus Tetrahymena (and often together with small amounts of its isomer from the hopane series, diplopterol) (Mallory et al., 1963; Elliott, 1973), in the fern Oleandra wallichii (Zander et al., 1969) and in cultures of the anaerobic rumen fungus Piromonas communis (Kemp et al., 1984). However, the abundance and ubiquity of gammacerane and tetrahymanol in marine sediments and palaeohypersaline environments led us to postulate that tetrahymanol should be far more widespread in living organisms (ten Haven et al., 1989, and references therein). Thus the discovery of tetrahymanol in Rhodopseudomonas palustris extends the significance of the gammacerane series as molecular fossil biomarkers, and might be the first record of a long list of prokaryotes capable of synthesizing such compounds.

This work was supported by the Ministère de l'Education Nationale (Réseau Européen de Laboratoires), by the Centre National de la Recherche Scientifique (Unité de Recherche Associée 135) and by the Bundesminister für Forschung und Technologie (Project 0318925 A7). We thank Mrs Elizabeth Krempp (Département de Chimie, Université Louis Pasteur, Strasbourg) for NMR measurements.

\section{References}

BOUvier, P., Berger, Y., RoHMer, M. \& OURisson, G. (1980). Nonspecific biosynthesis of gammacerane derivatives by a cell-free system from the protozoon Tetrahymena pyriformis. European Journal of Biochemistry 112, 549-556.

ElLtoTt, A. M. (1973). Life cycle and distribution of Tetrahymena. In Biology of Tetrahymena, pp. 256-286. Edited by A. M. Elliott. Stroudsbury: Dowden, Hutchinson \& Ross.

FlesCH, G. \& ROHMER, M. (1988). Prokaryotic hopanoids: the biosynthesis of the bacteriohopane skeleton. Formation of isoprenic units from two distinct acetate pools and a novel type of carbon/carbon linkage between a triterpene and D-ribose. European Journal of Biochemistry 175, 405-411.

ten Haven, H. L., Rohmer, M., Rullkötter, J. \& Bisseret, P. (1989). Tetrahymanol, the most likely precursor of gammacerane, occurs ubiquitously in marine sediments. Geochimica et Cosmochimica Acta 53, 3073-3079. 
Kemp, P., Lander, D. J. \& OrPin, C. G. (1984). The lipids of the rumen fungus Piromonas communis. Journal of General Microbiology 130, 27-37.

LIAAEN-JENSEN, S. (1962). The constitution of some bacterial carotenoids and their bearing on biosynthetic problems. Det Kongelige Norske Videnskabers Selskabs Skrifters 8, 180-182.

MaLlory, F. B., GoRdon, J. T. \& CONNER, R. L. (1963). The isolation of a pentacyclic triterpenoid alcohol from a protozoon. Journal of the American Chemical Society 85, 1362-1363.

NeUnLIST, S. \& ROHMER, M. (1988). A convenient route to an acetylenic $\mathrm{C}_{35}$ hopanoid and the absolute configuration of the sidechain of aminobacteriohopanetriol. Journal of the Chemical Society, Chemical Communications 830-832.

NeUnLIST, S., Bisseret, P. \& RohmER, M. (1988). The hopanoids of the purple non-sulfur bacteria Rhodopseudomonas palustris and Rhodopseudomonas acidophila and the absolute configuration of bacteriohopanetetrol. European Journal of Biochemistry 171, 242-252.

Ourisson, G., Rohmer, M. \& Poralla, K. (1987). Prokaryotic hopanoids and other sterol surrogates. Annual Review of Microbiology 41, 301-333.

RAEDERSTORFF, D. \& ROHMER, M. (1988). Polyterpenoids as cholesterol and tetrahymanol surrogates in the ciliate Tetrahymena pyriformis. Biochimica et Biophysica Acta 960, 190-199.
RATClifFe, R. \& RoDehoRst, R. (1970). Improved procedure for oxidations with chromium trioxide-pyridinium complex. Journal of Organic Chemistry 35, 4000-4001.

ROHMER, M., Bouvier, P. \& OURISSON, G. (1979). Molecular evolution of biomembranes: structural equivalents and phylogenetic precursors of sterols. Proceedings of the National Academy of Sciences of the United States of America 76, 847-851.

RoHMER, M., Bouvier-NAVE, P. \& OURISSON, G. (1984). Distribution of hopanoid triterpenes in prokaryotes. Journal of General Microbiology 130, 1137-1157.

WILKINS, A. L., BIRD, P. W. \& JAGER, P. M. (1987). Carbon-13 NMR of some triterpenes of the hopane group. Magnetic Resonance in Chemistry 25, 503-507.

WitTstrucK, T. A. \& Caspi, E. (1977). Assignment of the methyl resonances in the ${ }^{1} \mathbf{H}$ n.m.r. of tetrahymanol and tetrahymanone. Journal of Chemical Research (S), 180-181.

Zander, J. M., Caspi, E., Pandey, G. N. \& Mitra, C. R. (1969). The presence of tetrahymanol in Oleandra wallichii. Phytochemistry 8 , 2265-2267. 